\title{
Effects of waterlogging on the
} solubility and redox state of $\mathrm{Sb}$ in a shooting range soil and its uptake

\section{by grasses \\ A tank experiment}

\section{Journal Article}

\section{Author(s):}

Wan, Xiao-ming; Tandy, Susan; Hockmann, Kerstin; Schulin, R.

Publication date:

2013-10

\section{Permanent link:}

https://doi.org/10.3929/ethz-b-000072330

Rights / license:

In Copyright - Non-Commercial Use Permitted

Originally published in:

Plant and Soil 371(1-2), https://doi.org/10.1007/s11104-013-1684-2 


\title{
Effects of waterlogging on the solubility and redox state of $\mathrm{Sb}$ in a shooting range soil and its uptake by grasses: a tank experiment
}

\author{
Xiao-ming Wan • Susan Tandy • \\ Kerstin Hockmann • Rainer Schulin
}

Received: 31 October 2012 / Accepted: 7 March 2013 / Published online: 19 March 2013

(C) Springer Science+Business Media Dordrecht 2013

\begin{abstract}
Aims The effects of waterlogging on redox state and solubility of antimony $(\mathrm{Sb})$ in a calcareous shooting range soil and its uptake by forage grass Lolium perenne L. and pasture weed Holcus lanatus L. were investigated.

Methods Grasses were grown on semi-waterlogged or waterlogged shooting range soil in a laboratory tank. The soil solution was sampled at various depths over time and analyzed for the concentrations of $\mathrm{Sb}$ (III), $\mathrm{Sb}(\mathrm{V})$ and total $\mathrm{Sb}$, as well as other trace elements.
\end{abstract}

\section{Responsible Editor: Fangjie Zhao.}

Electronic supplementary material The online version of this article (doi:10.1007/s11104-013-1684-2) contains

supplementary material, which is available to authorized users.

X.-m. Wan

Chinese Academy of Sciences, Institute of Geographic

Sciences and Natural Resources Research,

Beijing 100101, China

e-mail: wanxm.06s@igsnrr.ac.cn

X.-m. Wan $\cdot S$. Tandy $(\bowtie) \cdot K$. Hockmann $\cdot$ R. Schulin

ETH Zürich, Institute of Terrestrial Ecosystems,

Universitätstrasse 16 ,

CH-8092 Zürich, Switzerland

e-mail: susan.tandy@env.ethz.ch

K. Hockmann

e-mail: kerstin.hockmann@env.ethz.ch

R. Schulin

e-mail: rainer.schulin@env.ethz.ch

X.-m. Wan

University of Chinese Academy of Sciences,

Beijing 100049, China
Results Although the reduction of $\mathrm{Sb}(\mathrm{V})$ to $\mathrm{Sb}(\mathrm{III})$ under increased waterlogging time decreased $\mathrm{Sb}$ solubility, it increased $\mathrm{Sb}$ uptake by $L$. perenne from 1.1 to $1.7 \mathrm{mgkg}^{-1}$ (and to a lesser extent H. lanatus), implying preferential uptake of $\mathrm{Sb}(\mathrm{III})$ by this grass. The tank showed considerable variation in redox conditions with depth and plant treatment. The soil root zone $(30 \mathrm{~cm}$ for $L$. perenne and $15 \mathrm{~cm}$ for $H$. lanatus) instead of the water saturated bottom, showed the highest manganese $(\mathrm{Mn})$ and iron $(\mathrm{Fe})$ concentrations in solution, accompanied by a higher proportion of $\mathrm{Sb}$ (III) in solution than the bottom zone of the tank.

Conclusions Waterlogging can increase the risk of $\mathrm{Sb}$ entering the food chain from shooting range soil.

Keywords Antimony · Forage grass $\cdot$ Redox species $\cdot$ Shooting range soil $\cdot$ Vertical variability $\cdot$ Waterlogging

\section{Introduction}

Antimony $(\mathrm{Sb})$ is ubiquitously present in the environment at low concentrations. The background value in soil is less than $1 \mathrm{mgkg}^{-1}$ (Filella et al. 2007). In the recent past, human activities have caused locally elevated concentrations of $\mathrm{Sb}$ in the environment. In mining areas $\mathrm{Sb}$ concentrations of up to $15,000 \mathrm{mgkg}^{-1}$ have been reported (Baroni et al. 2000). Shooting activities are another source of soil contamination with $\mathrm{Sb}$. In Switzerland approximately 10-25 t of Sb enter soil as 
a result of military shooting activities each year (Mathys et al. 2007). In Norway a similar quantity was deposited from small arms ranges in the year 2000 (Stømseng and Ljønes 2000). The USA has about 12,000 shooting ranges (Bannon et al. 2009), so the predicted amount of $\mathrm{Sb}$ entering the environment in the USA is very large. Input of Sb into the environment with shooting also occurs from lead shot used for game and clay pigeon shooting. Based on a $2 \% \mathrm{Sb}$ content of lead shot (Migliorini et al. 2004), the estimated annual deposition of $\mathrm{Sb}$ is $41 \mathrm{t}$ in Canada (Cao et al. 2003) and about $100 \mathrm{t}$ in the UK (Ives K, BASC, UK, personal communication).

Antimony compounds are considered pollutants of primary concern by the Environmental Protection Agency of the United States (1979) and the Council of the European Communities (1998). Excessive exposure to $\mathrm{Sb}$ through ingestion and inhalation can cause deleterious health effects in humans and animals (Elinder and Friberg 1986; Sundar and Chakravarty 2010). However, despite the wide distribution of Sb contamination and its well known toxicity, the chemical behavior of $\mathrm{Sb}$ in the environment and the risks associated with $\mathrm{Sb}$ contamination are poorly understood.

Similar to its sister element arsenic (As), Sb exists mainly in its trivalent ( $\mathrm{Sb}(\mathrm{III})$ ) and pentavalent $(\mathrm{Sb}(\mathrm{V}))$ redox states in the environment (Arai 2010). Under anoxic conditions, $\mathrm{Sb}(\mathrm{III})$ is the main form, whereas $\mathrm{Sb}(\mathrm{V})$ dominates under oxic conditions. Antimony(III) is present in soil solution primarily as antimonite $\left(\mathrm{Sb}(\mathrm{OH})_{3}\right)$ and $\mathrm{Sb}(\mathrm{V})$ as antimonate $\left(\mathrm{Sb}(\mathrm{OH})_{6}{ }^{-}\right)($Cornelis et al. 2008). Antimonite is less soluble than antimonate and also adsorbs more strongly to Fe (hydr)oxides, the main Sb sorbents in soil, particularly at alkaline pH (Hammel et al. 2000; Mitsunobu et al. 2010). Antimony(III) is shown to have a higher toxicity than its pentavalent counterpart for both human beings and plants (Gebel 1997; He and Yang 1999).

The number of studies on the uptake of Sb by plants is still limited however and information on uptake mechanisms scarce. $\mathrm{Sb}$ (III) transporters belonging to the aquaglyceroporin subfamily have been identified in bacteria, yeast and mammals (Filella et al. 2007). Recently aquaglyceroporins contributing to Sb transport were identified in plant species Arabidopsis thaliana and Oryza sativa (Kamiya and Fujiwara 2009; Bienert et al. 2008), so it is postulated that this could be true for other plant species as well. Much less information is available for $\mathrm{Sb}(\mathrm{V})$. It has been suggested that it is transported by a different route to that of $\mathrm{Sb}$ (III) but this has not yet been identified (Filella et al. 2007). Due to the influence on the potential environmental risks of $\mathrm{Sb}$, redox transformations of $\mathrm{Sb}$ have received particular attention. Under aerobic conditions, Fe(III) and Mn(IV) (hydr)oxides can oxidize $\mathrm{Sb}$ (III) adsorbed to them and thus mobilize Sb (Leuz et al. 2006; Belzile et al. 2001). On the other hand, $\mathrm{Sb}(\mathrm{V})$ can be reduced to $\mathrm{Sb}(\mathrm{III})$ by $\mathrm{Fe}(\mathrm{II})$ in alkaline, anaerobic waters (Leuz et al. 2002). Fe(II) in the form of magnetite, mackinawite and green rust have also been reported to reduce $\mathrm{Sb}(\mathrm{V})$ (Kirsch et al. 2008; Mitsunobu et al. 2008).

As it is assumed that $\mathrm{Sb}$ is stable in well-aerated soils primarily in the form of $\mathrm{Sb}(\mathrm{V})$ (Filella et al. 2009), the study of $\mathrm{Sb}(\mathrm{V})$ reduction and its possible impacts on the safe use of soil has received little attention so far. However, there are many soils that are temporarily subject to reducing conditions due to waterlogging. If such soils are contaminated with $\mathrm{Sb}$, reductive dissolution of $\mathrm{Fe}$ or $\mathrm{Mn}$ (hydro) oxides can lead to the release of bound $\mathrm{Sb}$, despite $\mathrm{Sb}$ reduction to less mobile $\mathrm{Sb}$ (III) (Scheinost et al. 2006). In a pot experiment with a calcareous shooting range soil we found that after imposing reducing conditions, the total $\mathrm{Sb}$ concentrations in soil solution at first decreased due to the reduction of $\mathrm{Sb}(\mathrm{V})$ to $\mathrm{Sb}(\mathrm{III})$, but then exhibited a significant increase with the further decrease in redox potential due to the dissolution of $\mathrm{Fe}$ and Mn (hydr)oxides (Wan et al. 2013). More importantly, the increased concentration in dissolved $\mathrm{Sb}(\mathrm{III})$ resulted in an apparent increase in the uptake of Sb by forage plants, thus posing a higher risk than wellaerated soil. However, pot experiments can mimic the conditions and dynamics of waterlogged soils only to a limited degree as the development and activity of roots is confined to a rather small volume of shallow soil (Ray and Sinclair 1998; Huang et al. 1996; Audet and Charest 2010).

In this study, we investigated how waterlogging affected the redox species and solubility of $\mathrm{Sb}$ in a relocated calcareous shooting range soil and how these effects translated into $\mathrm{Sb}$ uptake by forage grasses using a tank system. The tank system represented conditions that were much closer to a field situation with regards to rooting space, soil water regime and aeration than small pots, but were still relatively well controlled and enabled easy sampling. 


\section{Materials and methods}

Experiment design The Sb contaminated soil used in the experiment was the same as used by Wan et al. (2013). It was collected from a military shooting range located in an alluvial plain along the Rhine River, next to the city of Chur in Eastern Switzerland $\left(9^{\circ} 30^{\prime} 11^{\prime \prime} \mathrm{E}\right.$ and $\left.46^{\circ} 51^{\prime} 19^{\prime \prime} \mathrm{N}\right)$. The soil was taken from the upper $30 \mathrm{~cm}$ depth of a field in the immediate vicinity of the stop butts. Sod and rooty materials were removed, and the remaining soil was homogenized on site and again in the laboratory. The soil was dried at $40{ }^{\circ} \mathrm{C}$ and sieved to $2 \mathrm{~mm}$. The soil properties are given by Conesa et al. (2011). The soil was a silty loam (US soil taxonomy), composed of $45 \%$ sand, $52 \%$ silt and $3 \%$ clay. The soil had a $\mathrm{CaCO}_{3}$ content of $15 \%$, a pH in water of 8.2 and an organic carbon content of $0.9 \%$. The total $\mathrm{Sb}$ and lead $(\mathrm{Pb})$ concentrations of the soil were approximately 21 and $500 \mathrm{mg} \mathrm{kg}^{-1}$, respectively. The percentage of $\mathrm{Sb}$ adsorbed to Fe and Mn hydr(oxide)s was $\sim 70 \%$ (Conesa et al. 2010).

Forty kilograms of soil were filled into a $70 \times 5 \times$ $60 \mathrm{~cm}$ plastic (polymethylmethacrylate) tank with water and air-tight walls and bottom. Two wells $(2 \times 3.5 \times$ $60 \mathrm{~cm}$ ) at the lateral sides of the tank each with a valve at the base allowed the regulation of the water table and the control of drainage (Fig. 1). To allow settling of the soil, the tank was slowly saturated from bottom up for 1 day by adding water through the wells, which were in hydraulic contact with the soil compartment through a porous screen, and then drained again by opening the valves for 3 days. This cycle was repeated three times, then the tank was drained for 1 week.

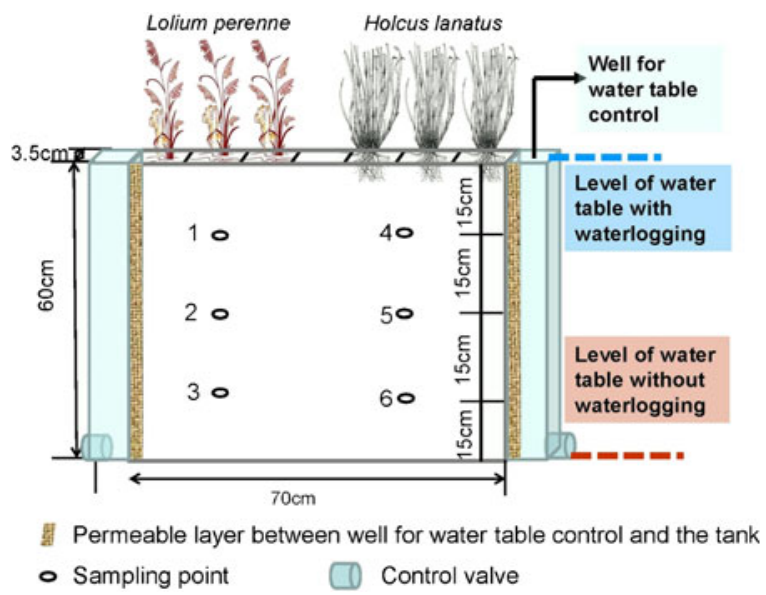

Fig. 1 Experimental tank design
During this wetting-draining cycle, the particle loss from the soil was insignificant. After this period six sampling holes with a diameter of $3 \mathrm{~mm}$ were drilled into the sidewalls, into which six soil solution samplers (Rhizon flex, $4 \mathrm{~cm}$ porous material, pore size $0.2 \mu \mathrm{m}, 2.5 \mathrm{~mm}$ outer diameter, and $12 \mathrm{~cm} \mathrm{PVC/PE}$ tubing, Rhizosphere Research Products, Wageningen, Netherlands) were inserted as illustrated in Fig. 1. After installation, the interspaces between samplers and walls were sealed with silica gel (which did not release any $\mathrm{Sb}$ or $\mathrm{Pb}$, as tested prior to the experiment). Lolium perenne L. and Holcus lanatus L. were selected as experimental grass species. The plants were germinated on the soil of the tank at a density of $10 \mathrm{gm}^{-2}$ after being soaked in $150 \mathrm{mgL}^{-1}$ gibberellic acid (Merck) for $48 \mathrm{~h}$.

Each species was planted in three compartments $(10 \times 3.5 \mathrm{~cm})$ with the middle compartment left free (Fig. 1). These seven compartments were separated in the surface layer $(\sim 5 \mathrm{~cm})$ but not below. Therefore, samplers at each depth collected soil solution representative for the whole horizon for each plant species. The plants were grown under drained conditions for 5 weeks at first, and then the soil was waterlogged for 15 weeks. During the non-waterlogging period, the valves on both sides of the tank were kept open, enabling excessive irrigation water to drain out. To induce waterlogging, the valves were closed and water was added through the side wells (with a porous screen between the well and tank) to the level of the soil surface and kept constant during the waterlogging period (Fig. 1). During the whole experiment, $20 \mathrm{~mL}$ water was added to each small planted compartment every 2 days in order to compensate for evapotranspiration losses during both the non-waterlogged and waterlogged time.

During the first 5 weeks of waterlogging, the soil solution was sampled every week. After these 5 weeks, i.e. after a total growth time of 10 weeks, the shoots were harvested by cutting them to $0.5 \mathrm{~cm}$ above the soil surface. Thereafter, the plants were allowed to regrow without reseeding for another 10 weeks under waterlogged conditions, before their shoots were harvested again as above. During the second growth period, the soil solution was sampled every 2 weeks. Harvested plants were rinsed in deionized water, and dried at $60{ }^{\circ} \mathrm{C}$ until constant weight was reached. The experiments were performed in a climate chamber with a daily photoperiod of $16 \mathrm{~h}$ at a light intensity $13,000 \mathrm{~lx}$ and $22{ }^{\circ} \mathrm{C}$ and a night period of $8 \mathrm{~h}$ at $14{ }^{\circ} \mathrm{C}$. 
Soil solution extraction and preservation To prevent the oxidation of $\mathrm{Sb}(\mathrm{III})$ in the sampled soil solution, samples of $0.4 \mathrm{~mL}$ soil solution were extracted through the rhizon-flex samplers using a nitrogenflushed syringe and immediately injected into a $1 \mathrm{~mL}$ plastic vial containing $0.4 \mathrm{~mL}$ argon-flushed 0.1 M EDTA solution. All Sb speciation analyses were completed within half an hour of solution extraction. After the sampling for $\mathrm{Sb}$ speciation analysis, another $10 \mathrm{~mL}$ soil solution was extracted through each sampling point, $3 \mathrm{~mL}$ of which was used to measure $\mathrm{pH}$, while the rest was acidified using $\mathrm{HNO}_{3}$ and preserved in a refrigerator at $4{ }^{\circ} \mathrm{C}$ for the later analysis of elemental concentrations. All elemental analyses were completed within 3 weeks of sampling.

Sb redox state speciation analysis Soil solution samples extracted for $\mathrm{Sb}$ redox speciation were analyzed by means of HPLC-ICP-MS (ICP-MS, ELAN DRC II, Perkin Elmer) using a strong anion exchange column (Hamilton PRP-X100, USA) and pump (880 PU, Jasco). The eluent contained $20 \mathrm{mM}$ EDTA (Merck), $2 \mathrm{mM}$ potassium hydrogen phthalate (Fluka), and $2 \%$ methanol, at $\mathrm{pH} 4$. The flow rate was $1 \mathrm{mLmin}^{-1}$, and the injection volume was $50 \mu \mathrm{L}$. Chemicals were of analytical grade or higher purity. Mixed standard solutions of $\mathrm{Sb}(\mathrm{V})$ and $\mathrm{Sb}(\mathrm{III})$ prepared from an $\mathrm{Sb}(\mathrm{V})$ stock solution of $1,000 \mathrm{mgL}^{-1} \mathrm{Sb}$ by dissolving $\mathrm{KSb}(\mathrm{OH})_{6}$ (Merck) in ultrapure water and an $\mathrm{Sb}$ (III) stock solution of $1,000 \mathrm{mgL}^{-1} \mathrm{Sb}\left(\mathrm{Sb}_{2} \mathrm{O}_{3}\right.$ in $2 \mathrm{M} \mathrm{HCl}$, Merck) were used to quantify the concentration of $\mathrm{Sb}(\mathrm{III})$ and $\mathrm{Sb}(\mathrm{V})$. The standard solutions were mixed with equal volumes of a $0.1 \mathrm{M}$ EDTA solution under oxygen free conditions. The detection limit, determined as three times the standard deviation $(\sigma)$ on the measured blanks $(n=10)$ for the speciation analysis was $0.2 \mu \mathrm{gL}^{-1}$ for both species.

Soil solution analysis The $\mathrm{pH}$ was measured by means of a Metrohm713 pH meter. Acidified soil solution extracts (see above) were analyzed for total concentrations of trace elements by ICP-MS (ELAN DRC II, Perkin Elmer) and for Fe by ICP-OES (Varian, VistaMPX CCS simultaneous). The detection limit $(3 \sigma)$ was $0.2 \mu \mathrm{gL}^{-1}$ for $\mathrm{Sb}, \mathrm{Pb}$ and $\mathrm{Mn}$ and $5 \mu \mathrm{gL}^{-1}$ for $\mathrm{Fe}$.

Plant sample analysis Plant samples were finely ground using a ceramic ball mill (Retsch MM-200, RETSCH Schieritz und Hauenstein AG) and digested in a Microwave (MLS-1200 MEGA ETHOS), using aliquots of $0.25 \mathrm{~g}$ plant material in $2 \mathrm{~mL} \mathrm{HNO}_{3}$ and $4 \mathrm{~mL} \mathrm{H}_{2} \mathrm{O}_{2}$, and made to a final volume of $25 \mathrm{~mL}$ with ultrapure water. The digests were analyzed in the same way as the soil solution samples. Certified Reference Material (ERM-CD281 Rye Grass) for plants was digested along with the samples for quality control. The mean \pm standard error of our measurements was $0.046 \pm 0.005 \mathrm{mgkg}^{-1}$ for $\mathrm{Sb}, 81 \pm 2 \mathrm{mgkg}^{-1}$ for $\mathrm{Mn}$, and $1.61 \pm 0.12 \mathrm{mgkg}^{-1}$ for $\mathrm{Pb}$, which agreed well with the certified values $\left(0.042 \pm 0.007 \mathrm{mgkg}^{-1}, 82 \pm 4 \mathrm{mgkg}^{-1}\right.$, and $1.67 \pm 0.11 \mathrm{mgkg}^{-1}$ for $\mathrm{Sb}, \mathrm{Mn}$ and $\mathrm{Pb}$, respectively) of these standards.

Statistics PASW statistics 18.0 was used for the statistical analysis of the data. ANOVA (LSD was used for multiple comparisons) was adopted to analyze elemental concentrations in plant samples. The significance level was set at an error probability of 0.05 .

\section{Results}

$\mathrm{Mn}$ and $\mathrm{Fe}$ concentrations in soil solution

In the soil compartment below L. perenne, the concentrations of dissolved $\mathrm{Mn}$ and $\mathrm{Fe}$ both increased within 1 week of waterlogging at the sampling depth of $30 \mathrm{~cm}$. In contrast, only low $\mathrm{Mn}$ concentrations and a much slower increase in $\mathrm{Mn}$, with large fluctuations, was found at $15 \mathrm{~cm}$ depth and almost no increase in $\mathrm{Fe}$ at $15 \mathrm{~cm}$ depth or for both metals at $45 \mathrm{~cm}$ depth (Fig. 2). The dissolved $\mathrm{Mn}$ concentrations at $30 \mathrm{~cm}$ depth also showed fluctuations between 1 and $2 \mathrm{mgL}^{-1}$ after the initial increase, while the $\mathrm{Fe}$ concentrations were much more stable $\left(\sim 2.5 \mathrm{mgL}^{-1}\right)$, implying a steady state. At the same time, the $\mathrm{pH}$ of the soil solution decreased, also with some fluctuations, from a $\mathrm{pH}$ close to 7.9 to values between 7.4 at $30 \mathrm{~cm}$ depth and 7.8 at $45 \mathrm{~cm}$ depth at the end of the experiment (Fig. 3).

Below H. lanatus, the change in $\mathrm{Mn}$ and Fe concentrations was quite different and less consistent than below L. perenne (Fig. 2). The dissolved Mn concentrations started to increase first after 3 weeks of waterlogging at the lowest sampling depth of $45 \mathrm{~cm}$, and then reached concentrations that were much higher than below L. perenne $\left(\sim 6 \mathrm{mgL}^{-1}\right)$. The Mn concentration at this depth remained highest compared to other depths except for a brief period shortly before the end of 
Fig. $2 \mathrm{Mn}(\mathbf{a}, \mathbf{b})$ and $\mathrm{Fe}$ concentration $(\mathbf{c}, \mathbf{d})$ in soil solution under waterlogged conditions
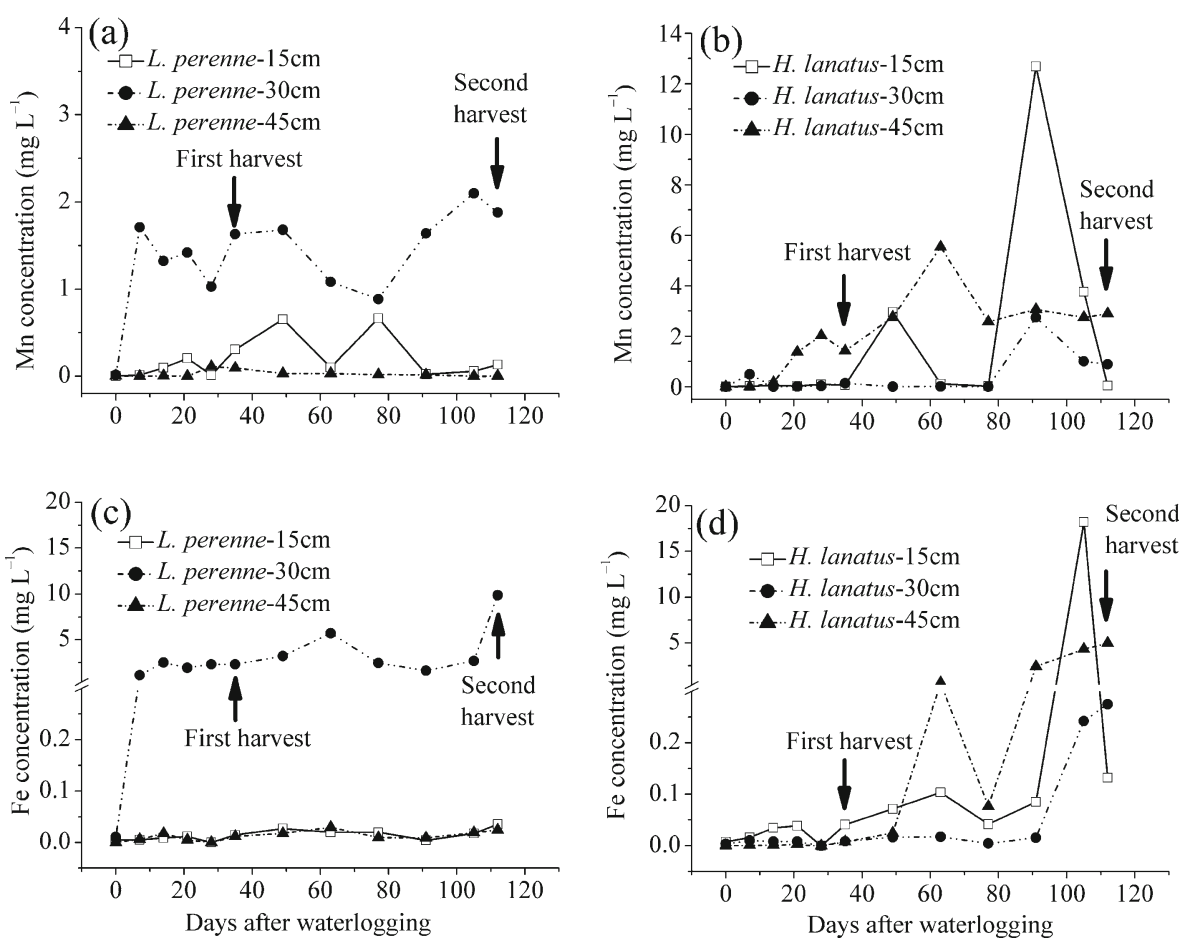

the experiment when a large peak of dissolved Mn at $15 \mathrm{~cm}$ depth reached $12.7 \mathrm{mgL}^{-1}$ on day 91 , followed by a drop back to $0.04 \mathrm{mgL}^{-1}$ on day 112 . The lowest Mn concentration was always detected at the depth of $30 \mathrm{~cm}$ throughout. The Fe concentrations showed a similar pattern (Fig. 2) with the main difference being that concentrations did not start to increase substantially at the depth of $45 \mathrm{~cm}$ within the first 7 weeks of waterlogging, while there was a small but gradual increase in dissolved $\mathrm{Fe}$ at the depth of $15 \mathrm{~cm}$ during this period. The Fe concentration at the depth of $30 \mathrm{~cm}$ was relatively consistent in the first 13 weeks and showed a gradual increase from day 91 until the end of the experiment. The highest dissolved $\mathrm{Fe}$ concentration below $H$. lanatus was recorded in the week before the final harvest at $15 \mathrm{~cm}$ depth with a singular peak that reached $18 \mathrm{mgL}^{-1}, 2$ weeks after the Mn peak. The overall decline in $\mathrm{pH}$ was stronger with larger fluctuations below H. lanatus than below L. perenne (Fig. 3).

$\mathrm{Sb}$ concentration and redox states in soil solution

Dissolved Sb concentrations (Fig. 4) showed much less variation between sampling depths than $\mathrm{Mn}$ and Fe concentrations. With increasing duration of waterlogging, the total $\mathrm{Sb}$ in solution gradually decreased at all three depths from initial concentrations of $50-90 \mu \mathrm{gL}^{-1}$ to constant concentrations of $13-18 \mu \mathrm{gL}^{-1}$ after 8 to 10 weeks of waterlogging below the plants of both species. Antimony (III) concentrations increased from below the detection limit to a maximum value of $\sim 2 \mu \mathrm{gL}^{-1}$ after around 5 weeks below $L$. perenne or a maximum of $\sim 4 \mu \mathrm{gL}^{-1}$ after around 7 weeks followed by a sharp decrease below H. lanatus (Fig. 5).

With an opposing trend to total $\mathrm{Sb}$, the relative abundance of $\mathrm{Sb}$ (III) (as a percentage of the sum of $\mathrm{Sb}(\mathrm{III})$ and $\mathrm{Sb}(\mathrm{V})$ ) increased, before reaching a steady value or even showing a trend to decrease again, with the exception of the samples taken at $15 \mathrm{~cm}$ depth below H. lanatus. The Sb(III) percentages of the latter increased until the last week before the final harvest and then showed a sudden drop. Below L. perenne, $\mathrm{Sb}$ (III) percentages were similar at $15 \mathrm{~cm}$ and $30 \mathrm{~cm}$ depth, at which they reached a plateau between $15 \%$ and $20 \%$ after 35 days of waterlogging, whereas they remained much lower at the $45 \mathrm{~cm}$ depth with a maximum value of close to $5 \%$. In contrast, below $H$. lanatus, there was more variation in $\mathrm{Sb}(\mathrm{III})$ percentages between sampling depths, with lowest values at $30 \mathrm{~cm}$ depth and highest values at $15 \mathrm{~cm}$ depth and a strongly widening gap during the second half of the waterlogging period, until it dropped in the last week. 

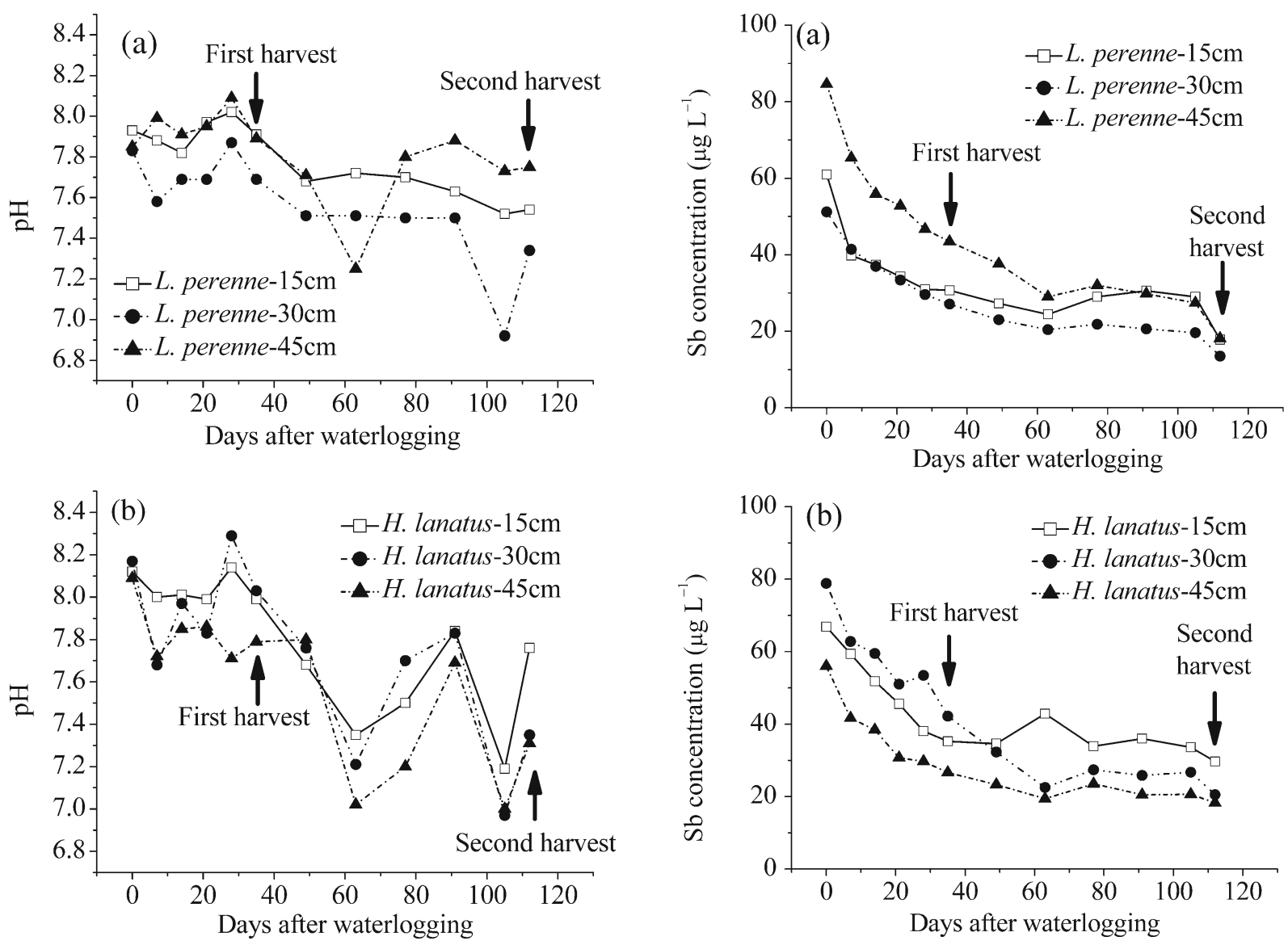

Fig. 3 The $\mathrm{pH}$ of soil solution under waterlogged conditions in the presence of L. perenne (a) and H. lanatus (b)

Interestingly, the peak in $\mathrm{Sb}(\mathrm{III})$ at $15 \mathrm{~cm}$ depth below $H$. lanatus coincided with the Fe peak at this sampling location. Apart from the latter peak, Sb(III) concentrations did not vary with depth below $H$. lanatus, and were lower and decreased more strongly with the duration of waterlogging at $45 \mathrm{~cm}$ than compared to the upper two sampling depths below L. perenne.

At the beginning of the experiment, the total $\mathrm{Sb}$ concentration was higher at the depth of $45 \mathrm{~cm}$ than at the other two sampling depths below $L$. perenne. Since $L$. perenne was grown for 5 weeks before waterlogging, and the roots reached the depth of $30 \mathrm{~cm}$, this initial difference among depths may have resulted from the uptake of $\mathrm{Sb}$ by $L$. perenne from the depths of 15 and $30 \mathrm{~cm}$.

Comparing these two plant species, the $\mathrm{Sb}$ (III) percentages at $15 \mathrm{~cm}$ depth were higher below L. perenne than below $H$. lanatus during the first 9 weeks of waterlogging. In the 11th week, with an apparent increase in $\mathrm{Sb}$ (III) percentages below H. lanatus, the $\mathrm{Sb}$ (III)

Fig. $4 \mathrm{Sb}$ concentration in soil solution under waterlogged conditions in the presence of L. perenne (a) and H. lanatus (b)

percentages at $15 \mathrm{~cm}$ below $H$. lanatus surpassed that below $L$. perenne but dropped at the final sampling point. $\mathrm{The} \mathrm{Sb}$ (III) percentages at $30 \mathrm{~cm}$ depth were higher below $L$. perenne than below $H$. lanatus while the $\mathrm{Sb}$ (III) percentages at $45 \mathrm{~cm}$ depth were lower below $L$. perenne than below $H$. lanatus throughout the experiment.

Sb concentrations in plants

Both plant species adapted well to the waterlogged conditions. There was no difference in biomass between the first and the second growth of the shoots (supporting information, Fig. S1), although H. lanatus shoots looked less healthy than those of $L$. perenne. The second-growth shoots, which grew entirely under waterlogged conditions, tended to accumulate more $\mathrm{Sb}$ than the first shoots that grew under 'semi-waterlogged' conditions (i.e. only waterlogged for the second half of their growing period) (Fig. 6), although the difference was not significant $(p>$ 
Fig. $5 \mathrm{Sb}$ (III) concentration (a, b) and $\mathrm{Sb}$ (III) percentage $(\mathbf{c}, \mathbf{d})$ in soil solution under waterlogged conditions
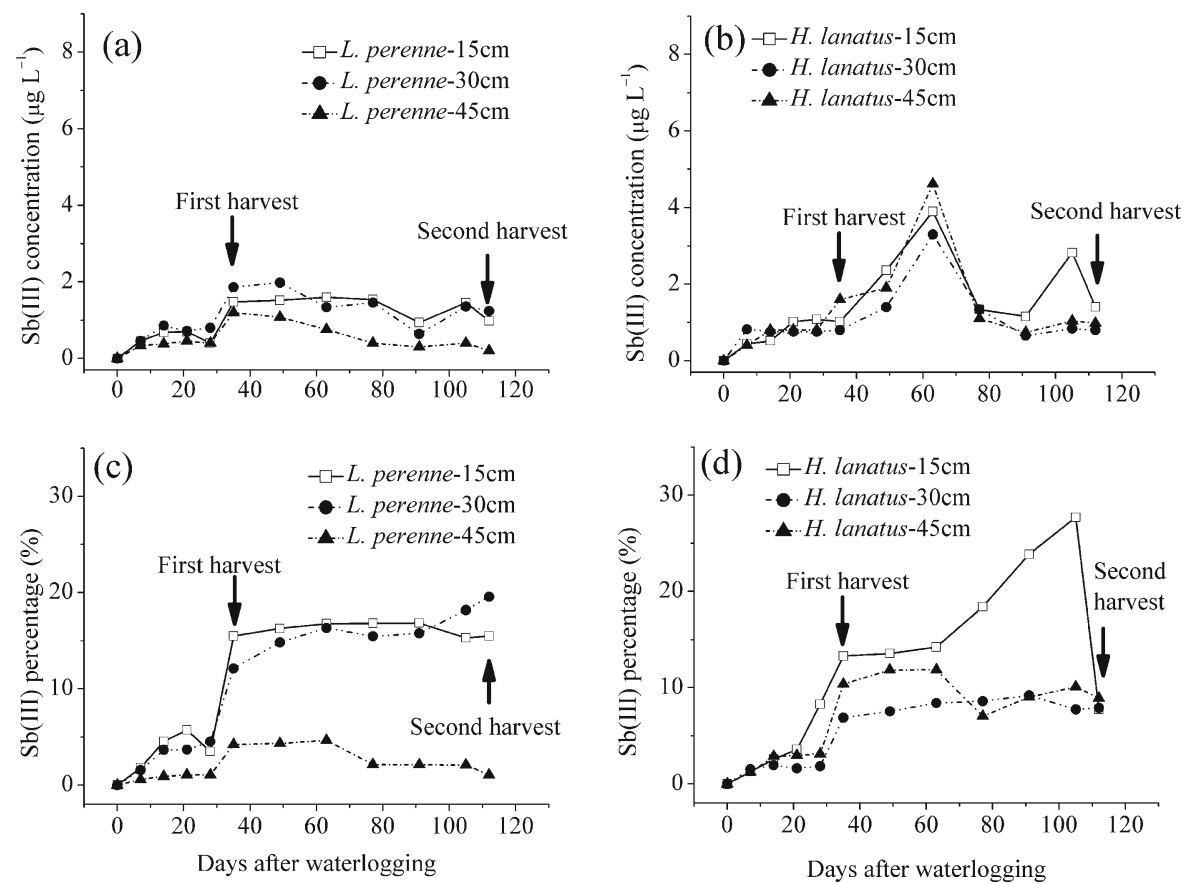

0.05). The $L$. perenne shoots did not only produce more biomass, but also accumulated higher $\mathrm{Sb}$ concentrations than H. lanatus in both stages of the experiment (Fig. 6).

$\mathrm{Pb}$ concentrations in soil solution and plants

The $\mathrm{Pb}$ concentration in soil solution below both species exhibited very similar behavior, i.e. a slight increase under waterlogged conditions from below the detection limit to $\sim 1.3 \mu \mathrm{gL}^{-1}$ followed by a fall to below the

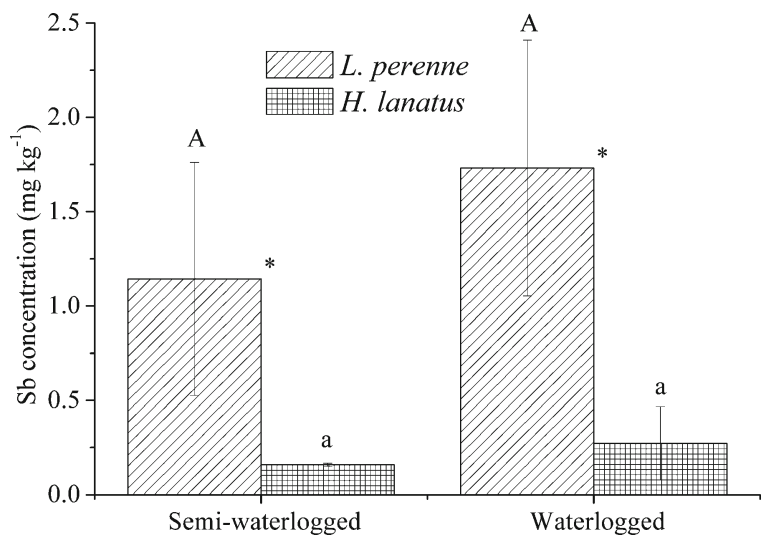

Fig. 6 Shoot $\mathrm{Sb}$ concentration of $L$. perenne and H. lanatus growing under different water regimes. The same letter indicates that the difference among treatments for each plant species was insignificant $(p>0.05)$. Asterisks indicate significant difference between plant species in the same treatment $(p<0.05)$ detection limit again (supporting information, Fig. S2). However, the shoot $\mathrm{Pb}$ concentration showed apparent difference between these two plant species. The shoot $\mathrm{Pb}$ concentration of $L$. perenne under entirely waterlogged conditions $\left(1.3 \pm 0.1 \mathrm{mg} \mathrm{kg}^{-1}\right)$ was $1 / 3$ of that under semiwaterlogged conditions $\left(4.9 \pm 2.3 \mathrm{mgkg}^{-1}\right.$ ), (supporting information, Fig. S3). Opposingly, the waterlogged $H$. lanatus $\left(5.8 \pm 1.0 \mathrm{mgkg}^{-1}\right)$ took up $93 \%$ more $\mathrm{Pb}$ than the semi-waterlogged ones $\left(3.1 \pm 1.0 \mathrm{mgkg}^{-1}\right)$.

\section{Discussion}

Waterlogging reduced $\mathrm{Sb}(\mathrm{V})$ to $\mathrm{Sb}(\mathrm{III})$ and increased its uptake by forage plants

Because redox potentials (Eh) at different depths in the tank system could not be measured due to technical restrictions, the concentrations of dissolved Fe and $\mathrm{Mn}$ were adopted as parameters reflecting the redox state of the soil. The increased $\mathrm{Fe}$ and $\mathrm{Mn}$ concentrations in the soil solution are evidence that the waterlogged treatment led to a strong reduction in the redox potential of the soil. According to the Eh-pH diagram of $\mathrm{Mn}$ and $\mathrm{Fe}$ solubility given by Cornelis et al. (2008), Mn and Fe (hydr)oxides are reduced and thus become soluble at Eh $<400 \mathrm{mV}$ and $\mathrm{Eh}<100 \mathrm{mV}$, respectively, at $\mathrm{pH} 7-8$ and the reduction of Fe (hydr)oxides occurs after Mn. This 
was in fact observed in our previous pot experiment using the same soil (Wan et al. 2013). Waterlogging in the tank experiment led to a decrease in redox potential, but apparently to a lesser extent than in the pot experiment, as evidenced by the difference in soluble $\mathrm{Mn}$ and Fe. This discrepancy may result from different increase extents of soil water content caused by waterlogging: an $80 \%$ increase in the pot and a $33 \%$ increase in the tank from non-waterlogged conditions. Another possible reason is the lower density of plant roots in the tank. The seed density at the beginning of the experiment in pots and tank was the same, but the tank had a larger volume.

The degree of reducing conditions in response to waterlogging is expected to increase with soil depth (Massmann et al. 2008), as oxygen diffusing into the soil from surface is gradually consumed. In fact, the $\mathrm{Mn}$ and $\mathrm{Fe}$ concentrations sampled below H. lanatus indicate that the redox potential here declined more quickly and more strongly at the bottom of the tank. However, the picture was very different below $L$. perenne. Here, the $\mathrm{Mn}$ and Fe concentrations revealed that the most reducing conditions occurred at medium depths, while only the slight increase in the concentrations of $\mathrm{Sb}(\mathrm{III})$ in soil solution at $45 \mathrm{~cm}$ depth showed also some decrease in redox potential at the lowest depth. Thomas et al. (2009) suggested that the degree of redox response to water table fluctuation decreased with an increase in soil depth due to the role of plants. As the two plant species had different rooting depths, the plants could indeed have affected the redox potential especially at depths of 15 and $30 \mathrm{~cm}$. Although H. lanatus is regarded as being able to adapt well to different water regimes (Turkington and Harper 1979), it had a more restricted rooting depth as we observed. At the end of the experiment, roots of $L$. perenne reached $30 \mathrm{~cm}$ depth, while roots of H. lanatus only reached the depth of $15 \mathrm{~cm}$. Given that plant root exudates can greatly affect soil chemistry through changing soil $\mathrm{pH}$, supplying carbon source for microbes, and affecting the composition of soil organic matter (Bowen and Rovira 1991; Nardi et al. 2000; Hinsinger et al. 2003), this difference in rooting depth may be the main reason for the observed differences in redox conditions below L. perenne and $H$. lanatus. In addition, oxygen supplied with the irrigation water infiltrating laterally from the two wells at the sides of the tank may also have had some effect.

Furthermore, it has to be considered that redox conditions are generally not in thermodynamic equilibrium in soils and often show large small-scale spatial and also short-term temporal variability in soils due to spatial heterogeneity and temporal fluctuations in the activity and growth of roots, microorganisms and other soil organisms (Yang et al. 2006). If soil is water-saturated, soil and root respiration can quickly deplete available oxygen and result in anaerobic soil conditions even at moderate rates of soil or root activities (Inglett et al. 2005), and result in a difference in redox potentials of several hundred $\mathrm{mV}$ within regions as small as $10 \mathrm{~cm}$ in diameter (Norrstrom 1994).

The strong variations in redox potential with time and position may also have been a major reason for the lack of strong correlations between the concentrations of Fe or $\mathrm{Mn}$ and the concentrations or percentages of $\mathrm{Sb}(\mathrm{III})$ in solution in our experiments $\left(R^{2}=0.2-0.4, p<0.05\right)$. This poor correlation furthermore indicates that there was only a weak relationship between the processes of reductive $\mathrm{Mn}$ and $\mathrm{Fe}$ (hydr)oxide dissolution and $\mathrm{Sb}$ immobilization. The decrease in dissolved Sb concentrations with waterlogging can partly be attributed to a dilution effect, as the water content of the soil increased by approximately $33 \%$. However, a dilution effect alone cannot explain the $55-79 \%$ decrease in the total concentration of $\mathrm{Sb}$ in solution. There are several other possible explanations: (1) stronger absorption of $\mathrm{Sb}(\mathrm{V})$ to $\mathrm{Fe} / \mathrm{Mn}$ (hydr)oxides due to a decrease in $\mathrm{pH}$ (Fig. 3); (2) improved adsorption of $\mathrm{Sb}(\mathrm{V})$ to the re-precipitated less crystalline $\mathrm{Fe}$ (hydr)oxides, as suggested by Mitsunobu et al. (2006); and (3) reduction of $\mathrm{Sb}(\mathrm{V})$ to $\mathrm{Sb}(\mathrm{III})$, with the latter having a greater absorption affinity to Fe (hydr)oxides (Mitsunobu et al. 2010). For our study, the last explanation is most reasonable, as there was no correlation between the $\mathrm{pH}$ values and $\mathrm{Sb}(\mathrm{V})$ concentrations in solution, and no evidence was observed indicating the re-precipitation of $\mathrm{Fe}$ (hydr)oxides. Therefore, it is suggested that $\mathrm{Sb}$ was removed from the soil solution after reduction from $\mathrm{Sb}(\mathrm{V})$ to $\mathrm{Sb}(\mathrm{III})$ due the much stronger sorption strength of the latter to $\mathrm{Fe}$ and $\mathrm{Mn}$ (hydr)oxides (Leuz et al. 2006; Mitsunobu et al. 2010).

On the other hand, with the dissolution of $\mathrm{Mn}$ and $\mathrm{Fe}$ (hydr)oxides, sorbed $\mathrm{Sb}$ would also be released (Takahashi et al. 2010; Mitsunobu et al. 2006). The latter process apparently did not become dominant during this experiment, in contrast to the pot experiment (Wan et al. 2013). It was probably part of the interplay of processes resulting in the approximately constant total $\mathrm{Sb}$ solution concentration towards the end of the experiment. In line with the lower Mn and Fe concentrations found in soil 
solution of the tank compared to the pot experiment, the concentrations and percentages of $\mathrm{Sb}$ (III) in soil solution were also lower in the tank than in the pots, again highlighting that conditions in the tank were less reducing.

In a similar pattern to the total $\mathrm{Sb}$ concentrations, the increase in soluble $\mathrm{Pb}$ in the waterlogged tank (Fig. S2) was less obvious than that in the pot, which may also result from the lower dissolution percentage of $\mathrm{Mn}$ and Fe (hydr)oxides caused by the less reducing conditions in the tank system (Miao et al. 2006; Phillips 1999).

Despite the decreased Sb concentration in soil solution, $\mathrm{Sb}$ accumulation by both grass species increased in the second part of the experiment. This result agrees with the findings of the pot experiment (Wan et al. 2013), where it has also been found that waterlogging decreased the solubility of $\mathrm{Sb}$ with the reduction of $\mathrm{Sb}(\mathrm{V})$ to $\mathrm{Sb}$ (III) but increased the $\mathrm{Sb}$ uptake by L. perenne. This may be a result of uptake of $\mathrm{Sb}$ (III) by aquaglyceroporins. $\mathrm{Sb}$ (III) transporters belonging to the aquaglyceroporin subfamily have been identified in plant species Arabidopsis thaliana and Oryza sativa (Kamiya and Fujiwara 2009; Bienert et al. 2008). This could be true for L. perenne as well, so there is preferential uptake of $\mathrm{Sb}(\mathrm{III})$. It was also shown however, that in mutant plants lacking this transport protein, $50 \%$ of $\mathrm{Sb}$ (III) taken up by the non-mutant plants was still taken up, implying that an additional uptake mechanism may be in play (Kamiya and Fujiwara 2009). The bioaccumulation factor (ratio of shoot $\mathrm{Sb}$ concentration in $\mathrm{mgkg}^{-1}$ to $\mathrm{Sb}$ concentration in soil solution in $\mathrm{mgL}^{-1}$ ) for $L$. perenne was $26 \pm 10$ under semi-waterlogged conditions and $68 \pm 26$ under waterlogged conditions, much higher than for H. lanatus, which was $3.3 \pm 0.2$ under semi-waterlogged conditions and 8.1 \pm 4.0 under waterlogged conditions. The increasing trend in $\mathrm{Sb}$ accumulation with increased exposure to waterlogging contrasted to the decreased total $\mathrm{Sb}$ concentration in the soil solution, but was in line with the increased concentration and percentage of dissolved $\mathrm{Sb}$ (III). This finding suggests that $\mathrm{Sb}$ was at least partially taken up from the pool of $\mathrm{Sb}$ (III) and explains why the bioaccumulation factor was roughly three times higher for both plant species in the second part of the experiment $(p<0.05)$. Tschan et al. (2009b) reported literature data suggesting that the uptake of Sb by plants is in general approximately proportional to the soluble $\mathrm{Sb}$ concentration in soil. Our results here indicate that redox state can make an important difference and needs to be taken into account in determining the uptake of $\mathrm{Sb}$ by plants.
In contrast to the pot experiment where a decrease in shoot $\mathrm{Sb}$ uptake of $H$. lanatus occurred under waterlogged conditions (Wan et al. 2013), shoot Sb concentration of this species growing in the tank increased with increasing waterlogging time, but the differences were not significant. H. lanatus has been reported to be an As tolerant plant species, inducing As(III) efflux to the external medium under As stress conditions (Logoteta et al. 2009). Antimony(III) and As(III) have similar chemical structures (Bienert et al. 2008; Wysocki et al. 2001), and they displayed a similar uptake mechanism in yeast (Wysocki et al. 2001; Ramanathan et al. 1997) and plants (Kamiya and Fujiwara 2009). In a number of micro-organisms, it was furthermore shown that $\mathrm{Sb}$ (III) efflux from cells is often mediated by an As(III) efflux protein (Filella et al. 2007). Therefore, in contrast to $L$. perenne, it is not likely that the As excluding species $H$. lanatus prefer to take up $\mathrm{Sb}(\mathrm{III})$ to $\mathrm{Sb}(\mathrm{V})$. In healthy roots, apoplastic bypass to shoots is minimal, but increases if the plant is subjected to anaerobic stress or physical damage (Moon et al. 1986; Hanson et al. 1985). Although the biomass of $H$. lanatus did not significantly change with waterlogging, the plants appeared less healthy than those of $L$. perenne. It is proposed that with increased waterlogging time, the waterlogged $H$. lanatus in the tank system experienced increased apoplastic bypass, which enabled more Sb to be transferred from roots to the xylem. This increased apoplastic bypass may also partly explain the increase in $\mathrm{Pb}$ uptake by $H$. lanatus under waterlogging (Fig. S3). The slight increase in dissolved $\mathrm{Pb}$ from below the detection limit to $\sim 1.3 \mu \mathrm{gL}^{-1}$ may have also played a role (Fig. S2), although the pot experiment showed that an increase in $\mathrm{Pb}$ in soil solution from 5 to $\sim 50 \mu \mathrm{gL}^{-1}$ did not significantly change the shoot $\mathrm{Pb}$ concentration (Wan et al. 2013). In contrast to H. lanatus, L. perenne showed a decrease in shoot uptake of $\mathrm{Pb}$ (Fig. S3). A decrease in the uptake of $\mathrm{Pb}$, As and potassium $(\mathrm{K})$ by the regrowth of plants has been reported in several studies (Cheng and Wong 2008; Gonzaga et al. 2008; Everaarts and van Beusichem 1998). In the tank system, the 2 nd harvested shoots also grew on existing roots; therefore, the decreased uptake of $\mathrm{Pb}$ by $L$. perenne may have resulted from this regrowth effect.

In general, the tank system showed less reducing conditions than the pot experiment, but a similar trend in both the change of soil chemical properties and the plant uptake characteristics. Because of its larger size and higher complexity, the tank allowed a study of the same 
processes under conditions that were closer to the process in real soils. An associated trade-off was that conditions were much less controllable than in the pot and only one treatment with no true replicates of the tank and the soil solution samples could be run at a time. To ensure that the soil solution was drawn from only one treatment, samplers had to be a certain distance apart and an area without plants of $10 \mathrm{~cm}$ was left between the two plant species to make sure there was no interaction between them. As a consequence, it was not possible to have replicate soil solution samplers for a particular treatment and depth or gain a true assessment of variability in soil solution. The large standard deviations of shoot $\mathrm{Sb}$ and $\mathrm{Pb}$ concentration (Fig. S3 \& Fig. 6) indeed imply differences between single compartments. Due to the lack of replicates and the increased complexity of the tank system, there still existed some issues that could not be easily interpreted, and which still require further investigation using a larger-scale and even more realistic system. Despite its limitations, this experiment provides information about the transport and transformation of $\mathrm{Sb}$ under different extents of plant activities and oxygen diffusion that are not possible from pot experiments alone and also reveals the heterogeneity of natural systems.

Practical implications

Shooting range soil contamination, mainly by $\mathrm{Sb}$ and $\mathrm{Pb}$, has received increasing attention in recent years due to the large number of shooting ranges across the world (Sorvari 2007; Lin 1996; Johnson et al. 2005; Bannon et al. 2009; Griggs et al. 2011; LaporteSaumure et al. 2011; Reid and Watson 2005; Stømseng and Ljønes 2000). The results of the pot experiment suggested that re-using moderately contaminated shooting range soils e.g. for pasture of cattle and sheep, as proposed by Tschan et al. (2009), should be feasible, but the risk of Sb entering food chains must be controlled and in particular the potential effects of variations in soil moisture have to be taken into account (Wan et al. 2013). However, solute accumulation rates are often quite different in pot experiments from that in the field. A tank system as used in this study represents field soil conditions better than pots, while still allowing much better control and monitoring of experimental conditions than a field site. Thus, the finding of similar $\mathrm{Sb}$ accumulation rates for L. perenne with both systems is important evidence demonstrating that, for some plants at least, there is indeed an increased risk of $\mathrm{Sb}$ transfer into the food chain under waterlogged conditions.

By Swiss regulations, shooting range soils must be treated as hazardous waste if the concentration of $\mathrm{Pb}$ exceeds $1,000 \mathrm{mgkg}^{-1}$ (The Swiss Federal Council 1998). Similar regulations apply in other countries. However, usually only small amounts of soil are so heavily contaminated as to require treatment as hazardous waste. Much larger amounts are only moderately contaminated and are still a valuable natural resource for plant production if adequate restrictions are imposed to control the risks. As disclosed by this study, the shoot $\mathrm{Pb}$ concentrations in both pot and tank experiments were far below the threshold concentration of $40 \mathrm{mgkg}^{-1}$ for fodder in Switzerland (BUWAL 2005), which is in accordance with the reported low mobility of $\mathrm{Pb}$ in plants (Comino et al. 2011). Thus, the main concern currently is the potential risks that could arise from the accumulation of $\mathrm{Sb}$.

The plant concentrations are compared with fodder concentrations for As because limits for Sb have not been established and $\mathrm{Sb}$ toxicity is believed to be comparable to that of As (Gebel 1997). The maximum allowed concentration of As in fodder is $2 \mathrm{mgkg}$ dry weight $^{-1}$ according to Swiss regulations (Baroni et al. 2000). The L. perenne growing in the waterlogged tank for 2 months had an average value close to that and one single value higher than that $\left(2.5 \mathrm{mgkg}\right.$ dry weight $\left.{ }^{-1}\right)$. If waterlogging lasted for a longer time or the plants were older, it is expected that the accumulation of $\mathrm{Sb}$ in the shoots of $L$. perenne would be even higher (Tighe et al. 2005). Therefore, $\mathrm{Sb}$ contamination of shooting range soils should remain the focus of attention (Johnson et al. 2005; Lewis et al. 2010), especially on lands temporarily or permanently under flooded conditions.

In summary, the results indicate that there is a potential risk of $\mathrm{Sb}$ transfer into the food chain in using Sb-contaminated shooting range soils for pasture or forage production if these soils are subject to waterlogging. Before the re-use of moderately contaminated shooting range soil, risk assessments must be performed that include addressing the risks that could arise from changing redox conditions.

Acknowledgment We gratefully acknowledge Dr. Dieter Ramseier from the Institute of Integrative Biology, ETH Zürich, for his suggestions in selecting plant species. We also thank Björn Studer and Martin Keller for their technical support. This work was funded by the Sino-Swiss Science and Technology Cooperation (SSSTC) Program (EG 19-032010). 


\section{References}

Arai Y (2010) Arsenic and antimony. In: Hooda PS (ed) Trace elements in soils. Wiley-Blackwell, London, pp 384-400

Audet P, Charest C (2010) Identification of constraining experimental-design factors in mycorrhizal pot-growth studies. J Bot 2010:1-6. doi:10.1155/2010/718013

Bannon DI, Drexler JW, Fent GM, Casteel SW, Hunter PJ, Brattin WJ, Major MA (2009) Evaluation of small arms range soils for metal contamination and lead bioavailability. Environ Sci Technol 43(24):9071-9076. doi:10.1021/ es $901834 \mathrm{~h}$

Baroni F, Boscagli A, Protano G, Riccobono F (2000) Antimony contents in plant species growing in an Sb-mining district (Tuscany, Italy). In: Markert B, Friese K (eds) Trace metals in the environment, vol 4. Elsevier, pp 341-361

Belzile N, Chen YW, Wang ZJ (2001) Oxidation of antimony (III) by amorphous iron and manganese oxyhydroxides. Chem Geol 174(4):379-387. doi:10.1016/s0009-2541(00)00287-4

Bienert GP, Thorsen M, Schussler MD, Nilsson HR, Wagner A, Tamas MJ, Jahn TP (2008) A subgroup of plant aquaporins facilitate the bi-directional diffusion of $\mathrm{As}(\mathrm{OH})_{3}$ and $\mathrm{Sb}(\mathrm{OH})_{3}$ across membranes. BMC Biol 6:26. doi:10.1186/1741-7007-6-26

Bowen GD, Rovira A (1991) The rhizosphere. In: Walsel Y, Eshel A, Kafkafi U (eds) Plant roots, the hidden half. Marcel Dekker, New York, pp 641-669

BUWAL (2005) Gefährdungsabschätzung und Massnahmen bei schadstoffbelasteten Böden. Bundesamt für Umwelt, Wald und Landschaft. Bern

Cao XD, Ma LQ, Chen M, Hardison DW, Harris WG (2003) Lead transformation and distribution in the soils of shooting ranges in Florida, USA. Sci Total Environ 307(13):179-189. doi:10.1016/s0048-9697(02)00543-0

Cheng JM, Wong MH (2008) Effects of earthworm (Pheretima SP.) on three sequential ryegrass harvests for remediating Lead/Zinc mine tailings. Int J Phytorem 10(3):173-184

Comino E, Menegatti S, Fiorucci A, Schwitzguebel JP (2011) Accumulation and translocation capacity of $\mathrm{As}, \mathrm{Co}, \mathrm{Cr}$ and $\mathrm{Pb}$ by forage plants. Agrochimica 55(2):105-115

Conesa HM, Wieser M, Gasser M, Hockmann K, Evangelou MWH, Studer B, Schulin R (2010) Effects of three amendments on extractability and fractionation of $\mathrm{Pb}, \mathrm{Cu}, \mathrm{Ni}$ and $\mathrm{Sb}$ in two shooting range soils. J Hazard Mater 181:845-850

Conesa HM, Wieser M, Studer B, Schulin R (2011) Effects of vegetation and fertilizer on metal and $\mathrm{Sb}$ plant uptake in a calcareous shooting range soil. Ecol Eng 37(4):654-658. doi:10.1016/j.ecoleng.2010.11.001

Cornelis G, Johnson CA, Van Gerven T, Vandecasteele C (2008) Leaching mechanisms of oxyanionic metalloid and metal species in alkaline solid wastes: a review. Appl Geochem 23(5):955-976. doi:10.1016/j.apgeochem.2008.02.001

Council of the European Communities (1998) Council Directive 98/83/EC of 3 November 1998 on the quality of water intended for human consumption

Elinder CG, Friberg L (1986) Antimony. In: Friberg L, Nordberg GF, Vouk V (eds) Handbook on the toxicity of metals, 2nd edn. Elsevier Science Publication, New York, pp 353-365

Everaarts AP, van Beusichem ML (1998) The effect of planting date and plant density on potassium and magnesium uptake and harvest by Brussels sprouts. J Agron Crop Sci 181(4):201-207

Filella M, Belzile N, Lett MC (2007) Antimony in the environment: a review focused on natural waters. III. Microbiota relevant interactions. Earth Sci Rev 80(3-4):195-217

Filella M, Williams PA, Belzile N (2009) Antimony in the environment: knowns and unknowns. Environ Chem 6(2):95-105. doi:10.1071/en09007

Gebel T (1997) Arsenic and antimony: comparative approach on mechanistic toxicology. Chem Biol Interact 107(3):131144

Gonzaga MIS, Santos JAG, Ma LQ (2008) Phytoextraction by arsenic hyperaccumulator Pteris vittata L. from six arseniccontaminated soils: repeated harvests and arsenic redistribution. Environ Pollut 154(2):212-218

Griggs CS, Martin WA, Larson SL, O'Connnor G, Fabian G, Zynda G, Mackie D (2011) The effect of phosphate application on the mobility of antimony in firing range soils. Sci Total Environ 409(12):2397-2403. doi:10.1016/j.scitotenv.2011.02.043

Hammel W, Debus R, Steubing L (2000) Mobility of antimony in soil and its availability to plants. Chemosphere 41(11):1791-1798. doi:10.1016/s0045-6535(00)00037-0

Hanson PJ, Sucoff EI, Markhart AH (1985) Quantifying apoplastic flux through red pine root systems using trisodium, 3-hydroxy5,8,10-pyrenetrisulfonate. Plant Physiol 77:21-24

He MC, Yang JR (1999) Effects of different forms of antimony on rice during the period of germination and growth and antimony concentration in rice tissue. Sci Total Environ 244:149-155

Hinsinger P, Plassard C, Tang C, Jaillard B (2003) Origins of root-mediated $\mathrm{pH}$ changes in the rhizosphere and their responses to environmental constraints: a review. Plant Soil 248(1):43-59. doi:10.1023/a:1022371130939

Huang C, Webb MJ, Graham RD (1996) Pot size affects expression of Mn efficiency in barley. Plant Soil 178(2):205-208. doi:10.1007/bf00011584

Inglett PW, Reddy KR, Corstanje R (2005) Anaerobic soils. In: Daniel H (ed) Encyclopedia of soils in the environment. Elsevier, Oxford, pp 72-78

Johnson CA, Moench H, Wersin P, Kugler P, Wenger C (2005) Solubility of antimony and other elements in samples taken from shooting ranges. J Environ Qual 34(1):248-254

Kamiya T, Fujiwara T (2009) Arabidopsis NIP1;1 transports antimonite and determines antimonite sensitivity. Plant Cell Physiol 50(11):1977-1981

Kirsch R, Scheinost AC, Rossberg A, Banerjee D, Charlet L (2008) Reduction of antimony by nano-particulate magnetite and mackinawite. Mineral Mag 72(1):185-189. doi:10.1180/minmag.2008.072.1.185

Laporte-Saumure M, Martel R, Mercier G (2011) Characterization and metal availability of copper, lead, antimony and zinc contamination at four Canadian small arms firing ranges. Environ Technol 32(7):767-781. doi:10.1080/ 09593330.2010.512298

Leuz AK, Hug S, Moench H, Wehrli B, Johnson CA (2002) The redox chemistry of antimony in lakes. Geochim Cosmochim Acta 66(15A):A450

Leuz AK, Hug SJ, Wehrli B, Johnson CA (2006) Iron-mediated oxidation of antimony(III) by oxygen and hydrogen peroxide compared to arsenic(III) oxidation. Environ Sci Technol 40(8):2565-2571. doi:10.1021/es052059h 
Lewis J, Sjostrom J, Skyllberg U, Hagglund L (2010) Distribution, chemical speciation, and mobility of lead and antimony originating from small arms ammunition in a coarsegrained unsaturated surface sand. J Environ Qual 39(3):863-870. doi:10.2134/jeq2009.0211

Lin Z (1996) Secondary mineral phases of metallic lead in soils of shooting ranges from Örebro County, Sweden. Environ Geol 27(4):370-375. doi:10.1007/bf00766707

Logoteta B, Xu XY, Macnair MR, McGrath SP, Zhao FJ (2009) Arsenite efflux is not enhanced in the arsenate-tolerant phenotype of Holcus lanatus. New Phytol 183(2):340348. doi:10.1111/j.1469-8137.2009.02841.x

Massmann G, Nogeitzig A, Taute T, Pekdeger A (2008) Seasonal and spatial distribution of redox zones during lake bank filtration in Berlin, Germany. Environ Geol 54(1):53-65

Mathys R, Dittmar J, Johnson A (2007) Antimony in Switzerland: a substance flow analysis. The Swiss Federal Office for the Environment (FOEN), Bern

Miao SY, DeLaune RD, Jugsujinda A (2006) Influence of sediment redox conditions on release/solubility of metals and nutrients in a Louisiana Mississippi River deltaic plain freshwater lake. Sci Total Environ 371(1-3):334-343. doi:10.1016/j.scitotenv.2006.07.027

Migliorini M, Pigino G, Bianchi N, Bernini F, Leonzio C (2004) The effects of heavy metal contamination on the soil arthropod community of a shooting range. Environ Pollut 129(2):331-340. doi:10.1016/j.envpol.2003.09.025

Mitsunobu S, Harada T, Takahashi Y (2006) Comparison of antimony behavior with that of arsenic under various soil redox conditions. Environ Sci Technol 40(23):7270-7276. doi:10.1021/es060694x

Mitsunobu S, Takahashi Y, Sakai Y (2008) Abiotic reduction of antimony(V) by green rust $\left(\mathrm{Fe}_{4}(\mathrm{II}) \mathrm{Fe}_{2}(\mathrm{III})(\mathrm{OH})_{12} \mathrm{SO}_{4} \cdot 3 \mathrm{H}_{2} \mathrm{O}\right)$. Chemosphere 70(5):942-947. doi:10.1016/ j.chemosphere.2007.07.021

Mitsunobu S, Takahashi Y, Terada Y (2010) mu-XANES evidence for the reduction of $\mathrm{Sb}(\mathrm{V})$ to $\mathrm{Sb}(\mathrm{III})$ in soil from $\mathrm{Sb}$ mine tailing. Environ Sci Technol 44(4):1281-1287. doi:10.1021/es902942z

Moon GJ, Clough BF, Peterson CA, Allaway WG (1986) Apoplastic and symplastic pathways in Avicennia marina (Forsk.) Vierh. Roots revealed by fluorescent tracer dyes. Aust J Plant Physiol 13:637-648

Nardi S, Concheri G, Pizzeghello D, Sturaro A, Rella R, Parvoli G (2000) Soil organic matter mobilization by root exudates. Chemosphere 41(5):653-658. doi:10.1016/s00456535(99)00488-9

Norrstrom AC (1994) Field-measured redox potentials in soils at the groundwater surface-water inferface. Eur J Soil Sci 45(1):31-36. doi:10.1111/j.1365-2389.1994.tb00483.x

Phillips IR (1999) Copper, lead, cadmium, and zinc sorption by waterlogged and air-dry soil. J Soil Contam 8(3):343-364

Ramanathan S, Shi WP, Rosen BP, Daunert S (1997) Sensing antimonite and arsenite at the subattomole level with genetically engineered bioluminescent bacteria. Anal Chem 69(16):3380-3384. doi:10.1021/ac970111p

Ray JD, Sinclair TR (1998) The effect of pot size on growth and transpiration of maize and soybean during water deficit stress. J Exp Bot 49(325):1381-1386. doi:10.1093/jexbot/ 49.325.1381
Reid BJ, Watson R (2005) Lead tolerance in Aporrectodea rosea earthworms from a clay pigeon shooting site. Soil Biol Biochem 37(3):609-612. doi:10.1016/ j.soilbio.2004.09.003

Scheinost AC, Rossberg A, Vantelon D, Xifra I, Kretzschmar R, Leuz AK, Funke H, Johnson CA (2006) Quantitative antimony speciation in shooting-range soils by EXAFS spectroscopy. Geochim Cosmochim Acta 70(13):3299-3312. doi:10.1016/j.gca.2006.03.020

Sorvari J (2007) Environmental risks at Finnish shooting ranges —a case study. Hum Ecol Risk Assess 13(5):1111-1146. doi:10.1080/10807030701506124

Stømseng A, Ljønes M (2000) Vertikal transport av tungmetaller i sandjord. Mobilitet, transport og fordeling av bly, kobber, antimon og sink i jordsmonn tilknyttet en $30 \mathrm{~m}$ utendørs skytebane på Sessvollmoen. FFI Rapport2000/06191. http://rapporter.ffi.no/rapporter/2000/ 06191.pdf accessed 03.05.2012

Sundar S, Chakravarty J (2010) Antimony toxicity. Int J Env Res Public Health 7(12):4267-4277. doi:10.3390/ ijerph7124267

Takahashi T, Shozugawa K, Matsuo M (2010) Contribution of amorphous iron compounds to adsorptions of pentavalent antimony by soils. Water Air Soil Pollut 208(1-4):165172. doi:10.1007/s11270-009-0156-Z

The Swiss Federal Council (1998) Ordinance relating to impacts on the soil of the Swiss Federal Council, $1^{\text {st }}$ of July 1998, SR 814.12. Eidgenössische Drucksachen- und Materialzentrale, Bern, p 12

Thomas CR, Miao S, Sindhoj E (2009) Environmental factors affecting temporal and spatial patterns of soil redox potential in Floriada Everglades wetlands. Wetlands 29(4):11331145

Tighe M, Ashley P, Lockwood P, Wilson S (2005) Soil, water, and pasture enrichment of antimony and arsenic within a coastal floodplain system. Sci Total Environ 347(13):175-186

Tschan M, Robinson BH, Nodari M, Schulin R (2009) Antimony uptake by different plant species from nutrient solution, agar and soil. Environ Chem 6(2):144-152. doi:10.1071/ en08103

Turkington R, Harper JL (1979) The growth, distribution and neighbour relationships of Trifolium Repens in a permanent pasture: I. Ordination, pattern and contact. J Ecol 67(1):201-218

USEPA (1979) Water related fate of the 129 priority pollutants. Vol 1. United States Environmental Protection Agency, Washington

Wan XM, Tandy S, Hockmann K, Schulin R (2013) Changes in $\mathrm{Sb}$ speciation with waterlogging of shooting range soils and impacts on plant uptake. Environ Pollut 172:53-60

Wysocki R, Chery CC, Wawrzycka D, Van Hulle M, Cornelis R, Thevelein JM, Tamas MJ (2001) The glycerol channel Fps 1p mediates the uptake of arsenite and antimonite in Saccharomyces cerevisiae. Mol Microbiol 40(6):13911401. doi:10.1046/j.1365-2958.2001.02485.x

Yang J, Hu Y, Bu R (2006) Microscale spatial variability of redox potential in surface soil. Soil Sci 171(10):747-753. doi:10.1097/01.ss.0000230127.86394.45 